\title{
THYROID FUNCTION STATUS IN PATIENTS WITH THYROID ASSOCIATED OPHTHALMOPATHY: A STUDY FROM NEPAL
}

\author{
Saurav Piya ${ }^{1}$, Jeena Gurung ${ }^{1}$, Anadi Khatri ${ }^{2}$ \\ ${ }^{1}$ Consultant, Birat Eye Hospital, Biratnagar, Nepal, 2Consultant Vitreo-Retinal Surgeon, Birat Eye \\ Hospital, Biratnagar, Nepal
}

\begin{abstract}
Introduction: Thyroid Eye Disease (TED) is an organ-specific autoimmune inflammatory incapacitating eye disorder usually associated with Graves' disease affecting the orbit.

Objectives: To determine thyroid function status in patients with thyroid-associated Ophthalmopathy. Methods: This is a hospital-based cross-sectional study of sixty three clinically diagnosed new cases of thyroid-associated ophthalmopathy done at Nepal Eye Hospital, Kathmandu from February 2012 to January 2013. Detailed history, systemic \& ocular examination with special emphasis on evaluation of extraocular movement, lid signs, exophthalmos with Hertel's exophthalmometer was done. Thyroid function test and endocrine consultation were also done in all cases.

Results: There were an equal distribution of TED with hyperthyroid (34.95\%) and euthyroid status (34.95\%). The most common presentation of both euthyroid and hypothyroid patient was tremor (13.4\%) and palpitation (13.45\%). The most common symptom of TED was foreign body sensation (54\%) but in TED with euthyroid and hypothyroid status, redness (22.2\%) and diminution of vision $(20.6 \%)$ were more frequent symptoms respectively. The most common presenting sign was Von Graefe's sign (69 \%). Among TED with hyperthyroid and hypothyroid status, Dalrymple's sign (29.3\%) and Mobius sign $(17.4 \%)$ were most common respectively.

Conclusion: Thyroid-associated ophthalmopathy is an important health concern among patients with a thyroid disorder. TED with hyperthyroid states present more severely than hypothyroid and euthyroid states. As TED occurred with a high prevalence in all thyroid states, a close collaboration between endocrinologists and ophthalmologists along with timely referrals of patients with any eye complaint is mandated.
\end{abstract}

Key Words: Graves Ophthalmopathy; Thyroid Function Tests; Nepal; Hyperthyroidism; Thyroid Diseases; Hypothyroidism; Euthyroid; Referral and Consultation

\section{Introduction}

Thyroid-associated ophthalmopathy (orbitopathy) (TAO) or more commonly known as thyroid eye disease (TED) is a matter of important health concern among patients with a thyroid disorder.

A number of theories have been put forward to explain the unusual association of the disorder with thyroid autoimmunity. Most of them favor the role of autoimmunity in orbital preadipocytes against

\section{Correspondence Author}

Dr.Anadi Khatri

Department of Vitreo-Retina Disease and Surgery, Birat Eye Hospital

Biratnagar, Nepal

Phone no: 9779841767205

Email:anadikc@gmail.com a thyroid- stimulating hormone receptor (TSHr)-like protein and possibly extraocular muscle fibers, although environmental and genetic factors are also considered important. ${ }^{1}$ The pathogenesis of ophthalmopathy is due to autoreactivity to the thyrotropin receptor \& appears to be cytokinemediated activation of fibroblasts, secretion of glycosaminoglycans by these cells and ultimately fibrosis. $^{2}$

The course of ophthalmic changes in thyroid eye disease is not necessarily related to thyroid function. Eye signs develop in $70-85 \%$ of patients within 18 months of thyroid disease detection. ${ }^{3}$ 
Exophthalmos and ophthalmoplegia usually reach their maximum in approximately 3 months and can then remain stationary for an indefinite period of time or gradually subside with or without treatment. ${ }^{4}$ However, complete subsidence is rare. It is more common for the considerable degree of protrusion and movement limitation to persist permanently despite all attempts at improvement.

Among the patients with TAO, approximately 90\% have Graves's hyperthyroidism, $6 \%$ are euthyroid, 3\% have Hashimoto thyroiditis and 1\% have primary hypothyroidism. ${ }^{5}$ However, it must be noted that most hypothyroid patients who have been treated for previous hyperthyroidism and most patients with euthyroid ophthalmopathy develop or have subtle dysfunction of the thyroid. Among those patients with euthyroid orbitopathy, approximately $25 \%$ will develop thyroid dysfunction within 1 year and $50 \%$ within $5 \mathrm{yrs}^{2}$ Approximately $25-50 \%$ of patients with Grave's disease have or will develop clinically apparent TED for which 3-5\% requires intensive treatment or surgical intervention. Subclinical orbital alterations can, however, be seen on USG or CT in almost all cases.

NOSPECS is six-part classification of the changes of Graves' disease, in Class 0: No sign \& symptoms, Class 1: Only signs are upper eyelid retraction, lid lag, stare, Class 2: Soft tissue signs and symptoms : resistance to retropulsion, edema of conjunctiva and caruncle, lacrimal gland enlargement, injection over horizontal muscle insertion, edema of eyelids, fullness of eyelids, Class 3: Proptosis, Class 4: Extraocular muscle involvement Class 5: Corneal involvement secondary to exposure, Class 6: Sight loss secondary to optic nerve compression. ${ }^{6}$

Nepal is an endemic area of iodine deficiency. In iodine-deficient regions, iodine supplementation precipitates the hyperthyroidism of Graves and other types of hyperthyroidism through the JodBasedow phenomenon. ${ }^{2}$ Thyroid dysfunction and prevalence of goiter higher than average is a major public health problem in the local population. In the study done in the eastern part of Nepal, cases of hyperthyroidism and hypothyroidism were found to be $13.68 \%$ and $17.19 \%$ respectively. $^{7}$

Considering the high rate of TED among patients with or without thyroid disorders and its significant contribution to a patient's morbidity and mortality, TED has become an important health concern.

\section{Methods}

This is a hospital-based cross-sectional study of Sixty three clinically diagnosed new cases of thyroid-associated ophthalmopathy done at Nepal Eye Hospital, Kathmandu from Feb 2012 to Jan 2013. A detailed history was documented, including the age of onset, gender, ethnicity, geographical distribution, presenting complaints, general, ocular and systemic examination with their findings. Anterior segment examination was done by Haag Streit 900 Slit Lamp Bio microscopy. Evaluation of extraocular movement, lid signs of TED, exophthalmos with Hertel's exophthalmometer, IOP (primary and differential) with Goldmann Applanation tonometer and dry eye with Schirmer's test were done in all cases. Fundus examination was done using Volk +90 diopter lens after dilatation with $1 \%$ Tropicamide. CT/MRI orbit was done in selected cases. Patients were sent for Thyroid function test (freeT3, T4, TSH) Endocrine consultation was also done in all cases.

The statistical analysis was carried out using SPSS 20. The study was approved by the IRB of the National Academy of Medical Sciences in Nepal and adheres to the tenets of the declaration of Helsinki.

\section{Results}

In this study, 63 patients were evaluated. Majority of patients had an equal distribution of TED with hyperthyroid and euthyroid status with bimodal peaks in the age group 21-30 years and 31-40 years. Females were more affected than males with a female/male ratio of 1.62:1. TED patients with hyperthyroid status were mainly affected in the earlier age group, i.e. 21- 30 years of age, and most were female. 


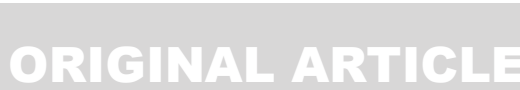

\section{Thyroid Function Status}

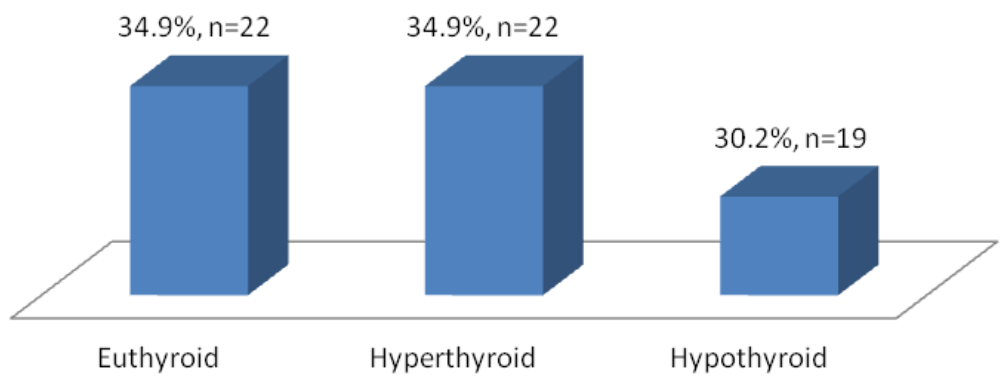

Figure 1: Distribution of patients according to Thyroid Function Status

Among 63 patients, $34.9 \%$ of cases were TED with hyperthyroid status and so were TED with euthyroid status (34.9\%). TED with hypothyroid status constituted $30.2 \%$.

Table 1: Distribution of ocular symptoms in different thyroid status

\begin{tabular}{|c|c|c|c|c|c|c|}
\hline \multirow[t]{2}{*}{ SYMPTOMS } & \multicolumn{2}{|c|}{$\begin{array}{c}\text { Euthyroid } \\
\text { N (\%) }\end{array}$} & \multicolumn{2}{|c|}{$\begin{array}{c}\text { Hyperthyroid } \\
\text { N (\%) }\end{array}$} & \multicolumn{2}{|c|}{$\begin{array}{c}\text { Hypothyroid } \\
\text { N }(\%)\end{array}$} \\
\hline & $\mathbf{R E}$ & $\mathbf{L E}$ & $\mathbf{R E}$ & LE & $\mathbf{R E}$ & LE \\
\hline REDNESS & $\begin{array}{c}14 \\
(22.2 \%)\end{array}$ & $\begin{array}{c}11 \\
(17.5 \%)\end{array}$ & $\begin{array}{c}11 \\
(17.5 \%)\end{array}$ & $\begin{array}{c}13 \\
(20.6 \%)\end{array}$ & $\begin{array}{c}6 \\
(9.5 \%)\end{array}$ & $\begin{array}{c}6 \\
(9.5 \%)\end{array}$ \\
\hline $\begin{array}{l}\text { FOREIGN BODY } \\
\text { SENSATION }\end{array}$ & $\begin{array}{c}13 \\
(20.6 \%)\end{array}$ & $\begin{array}{c}12 \\
(19 \%)\end{array}$ & $\begin{array}{c}15 \\
(23.8 \%)\end{array}$ & $\begin{array}{c}16 \\
(25.4 \%)\end{array}$ & $\begin{array}{c}6 \\
(9.5 \%) \\
\end{array}$ & $\begin{array}{c}6 \\
(9.5 \%) \\
\end{array}$ \\
\hline ITCHING & $\begin{array}{c}10 \\
(15.9 \%)\end{array}$ & $\begin{array}{c}8 \\
(12.7 \%)\end{array}$ & $\begin{array}{c}10 \\
(15.9 \%)\end{array}$ & $\begin{array}{c}11 \\
(17.5 \%)\end{array}$ & $\begin{array}{c}2 \\
(3.2 \%)\end{array}$ & $\begin{array}{c}2 \\
(3.2 \%)\end{array}$ \\
\hline DOUBLE VISION & $\begin{array}{c}1 \\
(1.6 \%)\end{array}$ & $\begin{array}{c}0 \\
(0 \%)\end{array}$ & $\begin{array}{c}2 \\
(3.2 \%)\end{array}$ & $\begin{array}{c}3 \\
(4.8 \%) \\
\end{array}$ & $\begin{array}{c}6 \\
(9.5 \%) \\
\end{array}$ & $\begin{array}{c}6 \\
(9.5 \%) \\
\end{array}$ \\
\hline OCULAR PAIN & $\begin{array}{c}11 \\
(17.5 \%)\end{array}$ & $\begin{array}{c}8 \\
(12.7 \%)\end{array}$ & $\begin{array}{c}12 \\
(19 \%)\end{array}$ & $\begin{array}{c}13 \\
(20.6 \%)\end{array}$ & $\begin{array}{c}3 \\
(4.8 \%)\end{array}$ & $\begin{array}{c}4 \\
(6.3 \%)\end{array}$ \\
\hline $\begin{array}{l}\text { DIMINUTION OF } \\
\text { VISION }\end{array}$ & $\begin{array}{c}6 \\
(9.5 \%)\end{array}$ & $\begin{array}{c}6 \\
(9.5 \%)\end{array}$ & $\begin{array}{c}14 \\
(22.2 \%)\end{array}$ & $\begin{array}{c}14 \\
(22.2 \%)\end{array}$ & $\begin{array}{c}13 \\
(20.6 \%)\end{array}$ & $\begin{array}{c}13 \\
(20.6 \%)\end{array}$ \\
\hline $\begin{array}{l}\text { FORWARD } \\
\text { PROTRUSION OF } \\
\text { EYE }\end{array}$ & $\begin{array}{c}5 \\
(7.9 \%)\end{array}$ & $\begin{array}{c}1 \\
(1.6 \%)\end{array}$ & $\begin{array}{c}14 \\
(22.2 \%)\end{array}$ & $\begin{array}{c}13 \\
(20.6 \%)\end{array}$ & $\begin{array}{c}5 \\
(7.9 \%)\end{array}$ & $\begin{array}{c}5 \\
(7.9 \%)\end{array}$ \\
\hline $\begin{array}{l}\text { WATERING } \\
\text { (LACRIMATION) }\end{array}$ & $\begin{array}{c}7 \\
(11.1 \%)\end{array}$ & $\begin{array}{c}6 \\
(9.5 \%)\end{array}$ & $\begin{array}{c}14 \\
(22.2 \%)\end{array}$ & $\begin{array}{c}13 \\
(20.6 \%)\end{array}$ & $\begin{array}{c}4 \\
(6.3 \%)\end{array}$ & $\begin{array}{c}7 \\
(11.1 \%)\end{array}$ \\
\hline $\begin{array}{l}\text { UNABLE TO CLOSE } \\
\text { EYE COMPLETELY } \\
\text { DURING SLEEP } \\
\text { (NOCTURNAL } \\
\text { LAGOPHTHALMOS) }\end{array}$ & 0 & 0 & $\begin{array}{c}7 \\
(11.1 \%)\end{array}$ & $\begin{array}{c}7 \\
(11.1 \%)\end{array}$ & 0 & 0 \\
\hline
\end{tabular}

Most common symptom of TED was foreign body sensation but in TED with euthyroid and hypothyroid status, redness and diminution of vision were more frequent symptoms respectively. 
Table 2: Distribution of ocular signs in different thyroid status:

\begin{tabular}{|c|c|c|c|c|c|c|}
\hline & \multicolumn{2}{|c|}{$\begin{array}{c}\text { Euthyroid } \\
\text { N (\%) }\end{array}$} & \multicolumn{2}{|c|}{$\begin{array}{c}\text { Hyperthyroid } \\
\text { N (\%) }\end{array}$} & \multicolumn{2}{|c|}{$\begin{array}{c}\text { Hypothyroid } \\
\text { N (\%) }\end{array}$} \\
\hline & $\mathbf{R E}$ & $\mathbf{L E}$ & $\mathbf{R E}$ & $\mathbf{L E}$ & RE & $\mathbf{L E}$ \\
\hline $\begin{array}{l}\text { Lid } \\
\text { retraction } \\
\text { (Dalrymple's } \\
\text { sign ) }\end{array}$ & $10(15.9 \%)$ & $\begin{array}{c}14 \\
(22.2 \%)\end{array}$ & $19(30.1 \%)$ & $\begin{array}{c}18 \\
(28.5 \%)\end{array}$ & $6(9.5 \%)$ & $7(11.1 \%)$ \\
\hline $\begin{array}{l}\text { Lid lag ( Von } \\
\text { Graefe's } \\
\text { sign) }\end{array}$ & $16(25.3 \%)$ & $\begin{array}{c}18 \\
(28.5 \%)\end{array}$ & $17(27 \%)$ & $17(27 \%)$ & $9(14.2 \%)$ & $10(15.9 \%)$ \\
\hline $\begin{array}{l}\text { Staring } \\
\text { appearance } \\
\text { (Kocher's } \\
\text { sign) }\end{array}$ & $6(9.5 \%)$ & $7(11.1 \%)$ & $13(20.6 \%)$ & $\begin{array}{c}13 \\
(20.6 \%)\end{array}$ & $4(6.3 \%)$ & $4(6.3 \%)$ \\
\hline $\begin{array}{l}\text { Fullness of } \\
\text { eyelid } \\
\text { ( Enroth's } \\
\text { sign) }\end{array}$ & $3(4.7 \%)$ & $2(3.1 \%)$ & $4(6.3 \%)$ & $3(4.7 \%)$ & $4(6.3 \%)$ & $4(6.3 \%)$ \\
\hline $\begin{array}{l}\text { Infrequent } \\
\text { blinking } \\
\text { ( Stellwag's } \\
\text { sign) }\end{array}$ & $4(6.3 \%)$ & $4(6.3 \%)$ & $6(9.5 \%)$ & $7(11.1 \%)$ & $3(4.7 \%)$ & $3(4.7 \%)$ \\
\hline $\begin{array}{l}\text { Convergence } \\
\text { deficiency } \\
\text { ( Mobius } \\
\text { sign) }\end{array}$ & $7(11.1 \%)$ & $7(11.1 \%)$ & $13(20.6 \%)$ & $12(19 \%)$ & $\begin{array}{c}11 \\
(17.4 \%)\end{array}$ & $11(17.4 \%)$ \\
\hline Proptosis & $5(7.9 \%)$ & 0 & $14(22.2 \%)$ & $\begin{array}{c}14 \\
(22.2 \%)\end{array}$ & $4(6.3 \%)$ & $4(6.3 \%)$ \\
\hline $\begin{array}{l}\text { Congestion at } \\
\text { site of } \\
\text { insertion of } \\
\text { EOM } \\
\text { (Goldzieher's } \\
\text { sign) }\end{array}$ & $1(1.6 \%)$ & 0 & $4(6.3 \%)$ & $4(6.3 \%)$ & $1(1.6 \%)$ & $1(1.6 \%)$ \\
\hline
\end{tabular}

Most common presenting sign of TED was Von Graefe's sign but in TED with hyperthyroid and hypothyroid status, (Dalrymple's sign) lid retraction and convergence deficiency (Mobius sign) were most common presenting signs respectively.

$12.6 \%$ of patients had extraocular muscle restriction. $7.9 \%$ had uniocular muscle restriction which was all abduction restriction with an equal proportion of TED with hyperthyroid status $(3.1 \%)$ and hypothyroid status (3.1\%).15.2\% had binocular extraocular movement restriction with majority had an equal proportion of version and elevation restriction. The maiority were in TED patient with hyperthyroid status $(11.2 \%)$ 


\section{ORICTNALARTHCH}

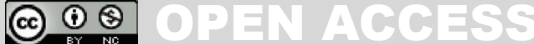

followed by TED with hypothyroid status (5.6\%).

$43 \%$ of cases had exophthalmos which was axial. Among which $45 \%$ had unilateral and $55 \%$ had bilateral exophthalmos.

Nearly $12.6 \%$ of the patients had SPKs secondary to exposure and $1.6 \%$ of the patient had both superior limbic-keratoconjunctivitis and marginal corneal ulcer. Majority of these patients having corneal complication were TED with hyperthyroid status. About $55.5 \%$ of patients had the dry eye of which the majority had moderate dry eye $(22.2 \%)$

In our study, $6.4 \%$ of the patients had increased intraocular pressure (differential) and the majority belonged to TED with hyperthyroid status (3.2\%). Only around $1.6 \%$ of TED with euthyroid status had increased primary intraocular pressure.

\begin{tabular}{|c|c|c|c|c|c|c|c|c|}
\hline NOSPECS & \multicolumn{2}{|c|}{ Euthyroid } & \multicolumn{2}{|c|}{ Hyperthyroid } & \multicolumn{2}{|c|}{ hypothyroid } & \multicolumn{2}{|c|}{ Total } \\
\hline $\begin{array}{l}\text { No signs } \\
\text { and } \\
\text { symptoms } \\
\text { CLASS 0 }\end{array}$ & $\begin{array}{c}\mathbf{R E} \\
1 \\
(1.6 \%)\end{array}$ & $\begin{array}{c}\text { LE } \\
1 \\
(1.6 \%)\end{array}$ & $\begin{array}{c}\mathbf{R E} \\
0\end{array}$ & $\begin{array}{c}\mathbf{L E} \\
0\end{array}$ & $\begin{array}{c}\text { RE } \\
2 \\
(3.1 \%)\end{array}$ & $\begin{array}{c}\text { LE } \\
2 \\
(3.1 \%)\end{array}$ & $\begin{array}{c}\mathbf{R E} \\
3 \\
(4.7 \%)\end{array}$ & $\begin{array}{c}\text { LE } \\
3 \\
(4.7 \%)\end{array}$ \\
\hline $\begin{array}{l}\text { Only signs } \\
\text { CLASS } 1\end{array}$ & $16(25.3 \%)$ & $\begin{array}{c}20 \\
(31.7 \%)\end{array}$ & $6(9.5 \%)$ & $\begin{array}{c}5 \\
(7.9 \%)\end{array}$ & $10(15.9 \%)$ & $\begin{array}{c}8 \\
(12.6 \%)\end{array}$ & $\begin{array}{c}32 \\
(50.7 \%)\end{array}$ & $\begin{array}{c}33 \\
(52.3 \%)\end{array}$ \\
\hline $\begin{array}{l}\text { Soft tissue } \\
\text { signs and } \\
\text { symptoms } \\
\text { CLASS } 2\end{array}$ & $\begin{array}{c}1 \\
(1.6 \%)\end{array}$ & $\begin{array}{c}1 \\
(1.6 \%)\end{array}$ & $1(1.6 \%)$ & $\begin{array}{c}1 \\
(1.6 \%)\end{array}$ & $3(4.7 \%)$ & $\begin{array}{c}3 \\
(4.7 \%)\end{array}$ & $\begin{array}{c}5 \\
(7.9 \%)\end{array}$ & $\begin{array}{c}5 \\
(7.9 \%)\end{array}$ \\
\hline $\begin{array}{l}\text { Proptosis } \\
\text { CLASS } 3\end{array}$ & $\begin{array}{c}4 \\
(6.3 \%)\end{array}$ & 0 & $\begin{array}{c}10 \\
(15.9 \%)\end{array}$ & $\begin{array}{c}11 \\
(17.4 \%)\end{array}$ & $3(4.7 \%)$ & $\begin{array}{c}2 \\
(3.1 \%)\end{array}$ & $\begin{array}{c}17 \\
(26.9 \%)\end{array}$ & $\begin{array}{l}13 \\
20.6 \%)\end{array}$ \\
\hline $\begin{array}{l}\text { EOM } \\
\text { involvement } \\
\text { CLASS } 4\end{array}$ & 0 & 0 & $2(3.1 \%)$ & $\begin{array}{c}2 \\
(3.1 \%)\end{array}$ & 0 & $\begin{array}{c}2 \\
(3.1 \%)\end{array}$ & $\begin{array}{c}2 \\
(3.1 \%)\end{array}$ & $\begin{array}{c}4 \\
(6.3 \%)\end{array}$ \\
\hline $\begin{array}{l}\text { Corneal } \\
\text { involvement } \\
\text { CLASS } 5\end{array}$ & 0 & 0 & $\begin{array}{c}3 \\
(4.7 \%)\end{array}$ & $\begin{array}{c}3 \\
(4.7 \%)\end{array}$ & $1(1.6 \%)$ & $\begin{array}{c}2 \\
(3.1 \%)\end{array}$ & $\begin{array}{c}4 \\
(6.3 \%)\end{array}$ & $\begin{array}{c}5 \\
(7.9 \%)\end{array}$ \\
\hline $\begin{array}{l}\text { Sight loss } \\
\text { CLASS } 6\end{array}$ & 0 & 0 & 0 & 0 & 0 & 0 & 0 & 0 \\
\hline
\end{tabular}


Majority of patients were in class 1 i.e, $51.5 \%$, of which $28.5 \%$ constituted TED with euthyroid status. It was followed by class 3 i.e, $23.75 \%$ and then by class 2 i.e, $7.9 \%$ in both eyes. TED with hyperthyroid status had more severe forms of TED while with euthyroid status had the least severe form.

\section{Discussion}

Thyroid ophthalmopathy (orbitopathy) is a matter of important health concern among patients with a thyroid disorder.

Majority of patients with Graves' ophthalmopathy was associated with hyperthyroidism, but in 5\% to $10 \%$ of cases, it is euthyroid. ${ }^{8}$ Mohsen Bahmani et al the suggested that majority of ophthalmopathy was associated with hypothyroidism (53.4\%) followed by $41.1 \%$ Graves' disease, $9.3 \%$ Hashimoto disease and 5.5\% euthyroid. ${ }^{9}$ In 2002 the study of Thyroid dysfunction in eastern Nepal by N Baral et al revealed the distribution of hyperthyroid and hypothyroidism to be $13.68 \%$ and $17.19 \%$ respectively. ${ }^{6}$ This study differs from most of the studies as the majority of patients had an equal distribution of TED with hyperthyroid (34.95\%) and euthyroid status (34.95\%) followed by $30.2 \%$ of hypothyroid status.

Although TAO is often associated with hyperthyroidism, it may occur in primary hypothyroidism, Hashimoto's thyroiditis, and sometimes in euthyroid individuals. Euthyroid Graves' disease patients had some mild thyroid abnormalities (thyroid auto antibodies, negative TRH test, negative T3 suppression test, and goiter) ${ }^{10,11}$ Patients with euthyroid TAO showed less active and severe clinical course, more unilateral involvement and lower levels of Thyroid receptor antibody (TRAb) than those in patients with hyperthyroid TAO. ${ }^{12}$

Patients with TED were relatively common at or beyond 40 years of age in most of the studies. In this study, TED with hyperthyroid status and hypothyroid status, the peak age range was 21-30 years and 41-50 years respectively whereas bimodal peak was present in TED with euthyroid status i.e., the age group 31-40 years \& 51-60 years.

Males are affected at an earlier age than female. ${ }^{13}$ Majority of the male patients were TED with euthyroid status whereas females were TED with hyperthyroid status. There is an association between severity of thyroid-associated ophthalmopathy and (i) advancing age and (ii) female-to-male ratio, which has not been previously described (iii) patients over the age of 60 with Graves' disease appear to be at risk of developing severe eye disease. ${ }^{1}$

In this study, the most frequent ocular symptom for TED with hyperthyroid status was foreign body sensation $24.6 \%$; whereas with hypothyroid status was a diminution of vision $20.6 \%$ and with euthyroid status, frequent symptom was redness $22.2 \%$.

Lid sign was found to be the most persistent sign of the orbitopathies (74\%). ${ }^{14}$ Upper eyelid retraction, either unilateral or bilateral, is documented in approximately $75 \%$ of patients at the time of diagnosis of thyroid eye disease (TED) ${ }^{5}$ In our study, lid retraction (Dalrymple's sign) was found in $58.7 \%$ which was not the most frequent sign.

In our study, the rates of the components of the NOSPECS classification system were $\mathrm{N}=4.7 \%$ , $\mathrm{O}=51.5 \%, \mathrm{~S}=7.9 \%, \mathrm{P}=23.7 \%, \mathrm{E}=4.7 \%$, $\mathrm{C}=7.1 \%$ and $\mathrm{S}=0 \%$. Majority of patients in class 1 were TED with euthyroid status. However, there were no patients in class 6 (sight loss).TED with hyperthyroid status had more severe forms of TED while with euthyroid status had the least severe form of the disease .

Dysthyroid patients were in the groups with severe Graves' ophthalmopathy. ${ }^{15}$ Thyroid dysfunction seemed to be associated with a more severe ophthalmopathy compared to the euthyroid state. ${ }^{16}$ This suggests that meticulous control of thyroid function also during antithyroid treatment 
is important in the management of Graves' ophthalmopathy.

\section{Conclusion}

Thyroid-associated ophthalmopathy is an important health concern among patients with a thyroid disorder. TED occurred with a high prevalence in all thyroid states, a close collaboration between endocrinologists and ophthalmologists along with timely referrals of patients with any eye complaint is mandated. Since this study was a hospital-based study the prevalence of thyroid dysfunction in TED may not be applicable to the general population. Extensive field-based countrywise epidemiological studies are necessary to provide data about thyroid dysfunction among TED in the community.

\section{Contributorship Statement:}

Dr. Saurav Piya and Dr. Jeena Gurung planned the study and was involved in participants 'enrollment, filling up questionnaires, Data Collection and Analysis. Dr. Anadi Khatri did the critical review of the manuscript. Final review of the manuscript was done by all the contributing authors.

\section{References}

1. P. Perros, A. L. Crombie*, J. N. S. Matthewst and P. Kendall-Taylor Age and gender influence the severity of thyroid-associated ophthalmopathy: a study of 101 patients attending a combined thyroid-eye clinic: Clinical Endocrinology (1993) 38, 367-372.

2. Anthony P. Weetman,M.D.,D.SC:Graves' Disease, The New England Journal of Medicine: October 26, 2000 pg:1236-1248:vol 343,No. 17.

3. Albert and Jokobiec's Principles and practice of ophthalmology third edition.4742-4755.

4. Duke -Elder System of ophhthalmology volume 13.937-964.

5. American academy of ophthalmology (orbit, eyelid and lacrimal system) basic and clinical science course 2009-2010.

6. Yanoff and Duker ophthalmology third edition.1036.

7. N Baral, M Lamsal, BC Koner and S Koirala. Department of Biochemistry, BP Koirala Institute of Health Sciences, Dharan, Nepal THYROID DYSFUNCTION IN EASTERN NEPAL , SOUTHEAST ASIAN J TROP MED PUBLIC Health, Vol 33 No. 3 September 2002.
8. PS Mallika, Ak Tan, S Aziz, Sar Syed Alwi, MS Chong, MR Vanithams, G Intan. Thyroid Associated Ophthalmopathy -Malaysian Family Physician 2009; Vol-1: 110-123.

9. Mohsen Bahmani Kashkouli1, Sara Jam2, Duman Sabzvari2, Nooshin Ketabi ,Shahrzad Azarinia, Seyed Ahmad SeyedAlinaghi, and Alireza Mofid3 : Thyroid-Associated Ophthalmopathy in Iranian Patients, Acta Medica Iranica, 2011; 49(9): 612-618.

10. Marcocci C, Bartalena L, Bogazzi F, et al. Studies on the occurrence of ophthalmopathy in Graves' disease. Acta Endocrinol (Copenh) 1989 Apr; 120(4) :473-8.

11. Reginald Hall Deborah Doniach Keith Kirkham David El Kabi. Ophthalmic Graves' Disease Diagnosis and Pathogenesis. The Lancet, February 21, 1970.

12. Raj Kumar Yadav, Namrata Thapa Magar, A Prevalence of Thyroid Disorder in Western Part of Nepal . J Clin Diagn Res. 2013 February; 7(2): 193196.

13. Scott and R. Michael Siatkowski; Thyroid Eye Disease.Seminarsin Ophthalmology, Vol 14, No 2 (June), 1999: pp 52-61.

14. Rajesh Rathi, Maria Nazish.Opthalmic Manifestation of Thyroid Orbitopathies,JLUMHS sept. 2009, vol:8 no 3.

15. Mark F. Prummel, Wilmar M. Wiersinga, Maarten $\mathrm{Ph}$. Mounts, Leo Koornneef, Arie Berghout, Ruth van der Gaag: Effect of Abnormal Thyroid Function on the severity of Graves' Ophthalmopathy. Arch Intern Med. 1990;150(5):1098-1101.

16. Kim J M, LaBree L, Levin L, Feldon SE. The relation of Graves' ophthalmopathy to circulating thyroid hormone status. Br J Ophthalmol. 2004 Jan;88(1): 72-4. 